\title{
A taxonomic revision of the genus Glaucium (Papaveraceae) in Iran
}

\author{
Zahra Tavakkoli ${ }^{1 \star}$, Mostafa Assadi $^{2}$ \\ ${ }^{1}$ Department of Plant Sciences, Faculty of Biological Sciences, Kharazmi University-Tehran, Iran \\ ${ }^{2}$ Department of Botany, Agricultural Research Education and Extension Organization (AREEO), Research Institute of \\ Forests and Rangelands, P. O. Box 13185-116-Tehran, Iran
}

\begin{abstract}
A taxonomic revision of the genus Glaucium (Papaveraceae) in Iran is presented. It reveals the presence of 10 species including 4 subspecies and 14 varieties. Two new taxa are described: G. yazdianum and G. vitellinum var. pilosum. G. yazdianum is related to G. calycinum in general, but is differentiated by shape and cellular structure of trichomes on young fruits and sepals, the shape of filaments and stem leaves and finally the length of siliquae and buds. Pollen and leaf epidermis morphology of these two species are compared, keeping this criterion in mind. G. pulchrum, G. elegantissimum and G. golestanicum are treated here as synonyms of G. oxylobum. An identification key to the genus Glaucium in Iran and for each taxon a morphological description and notes on their distribution and habitats are presented.
\end{abstract}

Keywords: Glaucium, Iran, new taxa, nomenclature, synopsis, taxonomy

\section{Introduction}

Papaveraceae s. str. was formerly divided into four subfamilies: Chelidoniodeae Ernest, Eschscholzioideae Ernest, Papaveroideae Ernest and Platystemonoideae Ernest (Ernest 1962- Kadereit 1993). Later on, Kadereit et al. (1994) included the subfamily of Platystemonoideae in Papaveroideae as well. The monophyly of two groups, Eschscholzioideae and Papaveroideae (including Platystemonoideae), was supported in phylogenetic analyses of Papaveraceae based on a combination of molecular and morphological data by Hoot et al. (1997). Glaucium Mill. and Dicranostigma Hook. f. et Thoms were also included as a part of Chelidonoideae while the morphological analysis of Kadereit et al. (1994) represented Glaucium and Dicranostigma as a sister group to Papaveroideae.

Glaucium is mainly distributed from Atlantic Europe to Central Asia (Kaderiet 1993). The genus comprises two sections and 23 species: sect. Acropetala Mory with four species, four subspecies and two varieties and sect. Glaucium with 19 species, eight subspecies and 16 varieties (Mory 1979). In Iran, it was represented by 11 (Cullen 1966) to 13 (Mobayen 1985; Gran and Sharifnia 2008) species, of these, five are endemics: G. calycinum Boiss., G. contortuplicatum Boiss., G. elegantissimum Mobayen, G. mathiolifolium Mobayen and $G$. golestanicum Gran \& Sharifnia. G. vitellinum Boiss. \& Buhse was reduced to the synonymy of G. oxylobum Boiss. \& Buhse and G. calycinum by Cullen (1966) and Mory (1979), respectively. Mobayen reduced this species to the ranks of variety and subspecies (1985): G. flavum Crantz var. vitellinum (Boiss. \& Buhse) Mobayen and G. flavum subsp. vitellinum (Boiss. \& Buhse) Mobayen, while it was introduced as a distinct species by Gran and Sharifnia (2008). G. leiocarpum Boiss. and G. elegans Fisch. \& C. A. Mey. var. integerrima Mobayen were placed as synonymous with G. flavum and $G$. elegans var. elegans, respectively (Tavakkoli 2016).

Trichomes morphology and their frequency and distribution have shown that they provide valuable characters for delimitation of taxa at sectional level (Vafadar et al. 2010). The structure and shape of trichomes are taxonomically significant for identification of Glaucium species as demonstrated by Mory (1979) but have not been studied in Iran so far.

The aims of this paper are to revise different taxa of Glaucium growing in Iran and to provide a revised synopsis and a diagnostic key for the genus in Iran.

\section{Materials and methods}

Most of the plant specimens were collected during the flowering period from natural populations of central, south

*Corresponding author, e-mail: zatavakkoli6@gmail.com; tavakoli@khu.ac.ir 
and north Iran. Deposited herbarium specimens in TARI, IRAN and FAR were also studied. Abbreviations are according to their B. index herbarium. In this study, leaves, stamens, young fruits and buds were collected from individuals in their natural habitats and herbarium dried specimens.

Trichomes were taken from young fruits and sepals. Materials were cleared in $0.1 \%$ sodium hypochlorite, stained with $0.1 \%$ fuchsine and mounted in glycerin jelly. The shape and cellular structure of about 50-60 trichomes were studied under a light microscope, using a Jenus microscope $32 \times$ to $400 \times$ magnifications with a Nikon camera.

The mature leaves of each taxon were macerated in 30\% $\mathrm{KOH}$ for about 3-4 hours. Then leaf epidermis samples were removed from the middle parts of the leaves, stained with $0.1 \%$ fuchsine and fixed in glycerin. Mostly three or more leaves were selected for each species and at least 3-5 slides prepared for each taxon. The stomata type, epidermal cells shape and pattern of anticlinal wall, length and width of stomata and stomata density per square millimeter of the leaf surface were recorded by light microscopy.

Pollen grains were prepared by means of the standard method of acetolysis (Erdtman 1986) and mounted on slides in glycerin jelly. Polar $(\mathrm{P})$ and equatorial $(\mathrm{E})$ axes and shape $(\mathrm{P} / \mathrm{E})$ of 30-50 pollen grains for each taxon were measured by Jenus microscope.

Measurements of trichomes, pollen grains and stomatal complexes for specimens were obtained using Micro Measure 1.04 software.

The terminology of pollen grains follows Hesse et al. (2009). The terminology of Payne (1978) and Van Cotthem (1970) were used for trichome morphology and leaf epidermis morphology, respectively.

\section{Results}

In this paper, 28 taxa of the genus Glaucium were recognized: 10 species, 4 subspecies and 14 varieties. As a result of this revision, G. vitellinum var. pilosum is reported as new for the flora of Iran. G. yazdianum is described as a new species from central Iran. G. pulchrum, G. elegantissimum and G. golestanicum are regarded as synonyms of G. oxylobum.

\section{Synopsis of the genus Glaucium Mill. in Iran}

Morphological description of the genus: Annual, biennial or perennial herbs. Stems with corymbose branches. Leaves lobed, pinnatifid or pinnatisect to pinnapartite and sometimes entire. Flowers solitary, axillary or terminal. Sepals 2, caduceus, with or without hair. Petals 4, yellow or orange, reddish orange, dark red, with or without spot. Stamens yellow or orange and numerous; anthers linear to oblong; filaments variable. Ovary linear, tuberculate, hairy or glabrous. Capsules siliquiform, linear to cylindrical, up to 28 $\mathrm{cm}$ long, with spongy septum, dehiscing by two valves. Stigma two lobed; lobes divergent, horizontal or curved. Seeds numerous, without appendages.

\section{Identification key to Iranian species of the genus Glaucium}

1. Capsules dehiscing from base to apex................... elegans Capsules dehiscing from apex to base ................................2

2. Ovaries or young siliquae densely pilose, villous or with adpressed or nearly spreading, soft and white hairs .........3 Ovaries or young siliquae tuberculate or with squamiform hairs or glabrous

\section{4}

3. Sepals $0.5-4 \mathrm{~cm}$ long; petals $1-4.5 \mathrm{~cm}$ long; fruiting pedicels exceeding the leaves subtending them.

..G. grandiflorum

Sepals and petals $1.5-3 \mathrm{~cm}$ long; fruiting pedicels shorter than the leaves subtending them ...............G. corniculatum

4. Young siliquae tuberculate, papillate or with conical squamiform hairs, occasionally glabrous; sepals $0.5-3(-3.5)$ $\mathrm{cm}$ long; petals yellow, reddish orange or deep red, with or without spot .................................................................... Young siliquae glabrous or hairy; sepals $1.5-5 \mathrm{~cm}$ long; petals yellow, with or without basal orange spot...............7

5. Stems with densely corymbose branches; sepals $0.5-1.5$ $(-1.8) \mathrm{cm}$ long; petals $0.5-1.5(-1.8) \mathrm{cm}$ long, yellow, with orange basal spot; siliquae mostly strongly contorted....... G. contortuplicatum Stems without densely corymbose branches; sepals up to $3 \mathrm{~cm}$ long; siliquae erect, arcuate or occasionally contorted

...6

6. Young siliquae densely covered with white tubercles; sepals hairy; petals yellow, reddish orange, with or without violet spot; mature siliquae erect or arcuate, glabrescens or occasionally with remote tubercles................... flavum Young siliquae tuberculate, papillate or with conical squamiform hairs or glabrous; sepals mostly glabrous; petals reddish orange, deep red or rarely yellow, with or without spot; mature siliquae arcuate or contorted and thickened at base, glabrescens or hairy G. oxylobum

7. Young siliquae glabrous, sometimes with scattered hairs near the apex; sepals up to $5 \mathrm{~cm}$ long............. G. vitellinum Young siliquae with squamiform hairs and often all along young siliqua, rarely glabrous; sepals up to $4 \mathrm{~cm}$ long ....8

8. Plants grey or dark grey; stems, branches and pedicels with patent hairs; young siliquae covered with long or very short and adpressed hairs; mature siliquae glabrescens, erect or arcuate ............................... G. mathiolifolium Plants green or glaucous; stems, branches and pedicels glabrous; young siliquae often covered with patent hairs, rarely hairs near the apex; mature siliquae hairy or glabrescens, arcuate or sometimes contorted

9. Sepals up to $4 \mathrm{~cm}$ long; petals up to $4.5 \mathrm{~cm}$ long; mature siliquae up to $20 \mathrm{~cm}$ long, with remote and nearly patent hairs or sometimes glabrescens; fruiting pedicels up to $10.5 \mathrm{~cm}$ long. G. calycinum Sepals up to $2.5 \mathrm{~cm}$ long; petals up to $3.5 \mathrm{~cm}$ long; mature siliquae $10-13 \mathrm{~cm}$ long, hairy, erect or arcuate; fruiting pedicels up to $6 \mathrm{~cm}$ long G. yazdianum 
1. G. corniculatum (L.) Curtis, Fl. Londin. 6: t. 32 (1780) (On-line Suppl. Tab. 1).

Type: Linnaeus 668/4 in Hungaria, Bohemia, Monspelii (Hb).

Synonyms: Chelidonium corniculatum L., Spec. Plant. 506 (1753); G. corniculatum (L.) Rudolf, Fl. Jen. Pl. 13 (1781).

Description: Biennial herbs, $12-38 \mathrm{~cm}$ high. Stems hairy. Stem leaves pinnatisect, semi-amplexicaul. Buds $1.5-3 \mathrm{~cm}$ long; sepals villous. Petals $1.5-3 \mathrm{~cm}$ long, red, yellow and orange at the base, with or without violet to blackish basal spot and sometimes spots with white margin. Anthers 1.5-3 $\mathrm{mm}$ long; filaments monotonic at upper half, broadened at lower part and gradually narrowed towards the base. Young siliquae covered with densely adpressed and white villous. Fruiting pedicels erect, $1.5-5 \mathrm{~cm}$ long. Mature siliquae 12-19 $\mathrm{cm}$ long, erect or arcuate, covered with semi-adpressed and white hairs; stigma 5-8 mm broad.

Phenology: Flowering in mid-May; with mature fruits in late June to late July.

Distribution and habitats: Europe, Turkey, Iran, Caucasus and Iraq. In fields, roadsides, steppe, weedy stony regions at $350-2000 \mathrm{~m}$ a. s. 1 .

Petals red, with black basal spot. var. corniculatum Petals yellow, orange at the base, with or without violet to black basal spot. var. flaviflorum

\section{G. corniculatum var. corniculatum}

Synonyms: Glaucium phoeniceum Crantz, Stirp. Austr., ed. 1, 2: 133 (1763); Chelidonium phoeniceum Lam., Fl. Fr., 1, 33: 169 (1778); G. corniculatum (L.) J. H. Rudolph var. phoeniceum (Crantz) DC., Syst. II.,: 97(1821); G. corniculatum (L.) J. H. Rudolph var. tricolor Loret \& Barrandon, Fl. Montp., 2; 22(1886) non Bernh; G. corniculatum (L.) J. H. Rudolph b. braunianum O. Kuntze, Acta Horti Petrop., 10: 149 (1887); G. corniculatum (L.) J. H. Rudolph $\alpha$. phoeniceum var. pilosum f. pinnatifidum O. Kuntze, 1. c., 147; G. corniculatum (L.) J. H. Rudolph var. purpureum Reverchon Pl. Andal., (1889); G. corniculatum (L.) J. H. Rudolph $\beta$. aurantiacum Rouy \& Fouc., Fl. Fr., 1 -2: 64 (1893-1895).

G. corniculatum var. flaviflorum DC. Syst., 2, 97 (1821).

Type: Steven, in litt.

Synonyms: Glaucium aureum C. Koch, Linnea, 19: 49 (1846); G. luteum Curtis, Fl. Matrit., 114 (1861); G. corniculatum (L.) J. H. Rudolph var. mauritanicum O. Kuntze, Acta Horti Petrop., 10: 140 (1887); G. corniculatum (L.) J. H. Rudolph B. caricum (Stapf) O. Kuntze, 1. c. p. 148; G. corniculatum (L.) J. H. Rudolph d. flavum (Crantz) O. Kuntze, 1. c. p. 148; G. corniculatum (L.) J. H. Rudolph $\delta$. flavum (Crantz) var. pilosum f. pinnatifidum O. Kuntze, 1. c. 148.

2. G. grandiflorum Boiss. \& Huet in Boiss., Diagn. Pl. Or. Nov. Sre 2 (5): 15 (1856) (Fig. 1A; On-line Suppl. Tab. 1)

Type: P. Huet, 7. 1853, Turkey: Erzeroum (P00739101).

Synonym: G. haussknechtii Bornm. \& Fedde in Engler, Pflanzenr. 40 (IV. 104) 227 (1909).
Description: Herbaceous biennial, 6-40 cm high, with one main stem or more. Stems branched, with moderate to rather dense hairs. Stem leaves pinnatifid or pinnatisect, semi-amplexicaul. Buds 0.5-4.5 cm long; sepals hairy. Petals 1-4.5 cm long, reddish orange or dark yellow, with a violet basal spot or darkish at the base. Stamens numerous; anthers 1-4 mm long; filaments monotonic in upper half, broadened in lower part and gradually narrowed towards the base. Young siliquae covered with densely adpressed or nearly spreading and soft hairs. Fruiting pedicels up to $9 \mathrm{~cm}$ long, erect or contorted, hairy. Mature siliquae 6-28 cm long, erect or contorted; stigma 4-9 mm broad.

Phenology: Flowering in late April, with mature fruits in mid-June to late July.

Ecology: Growing in dry stony places and hillsides at $180-2500 \mathrm{~m}$ a. s. 1 .

Siliquae and fruiting pedicels erect or arcuate subsp. grandiflorum

Siliquae contorted and fruiting pedicels refracted...... subsp. refractum

\section{G. grandiflorum subsp. grandiflorum}

Buds 2-4.5 cm long; petals reddish orange, $2-4.5 \mathrm{~cm}$ long.. ...var. grandiflorum

Buds 0.5-2 cm long; petals dark yellow, 1-2 cm long var. iranicum

\section{G. grandiflorum subsp. grandiflorum var. grandiflorum}

Distribution: Distributed in Europe, Turkey, Iran, Caucasus, Iraq, Syria and northern Africa.

G. grandiflorum subsp. grandiflorum var. iranicum Mory, Feddes Rep. 9 -10: 576 (1979).

Type: Haghighi s. n., 5. 8. 1964, Iran: Kurdestan, Boukan (W).

G. grandiflorum subsp. refractum (Nab.) Mory, Feddes Rep. 9 -10: 580 (1979).

Type: Noe 199, Iraq: Kurdestan; L. Baree s. n., 1852, Iran: Lorestan (syntype: JE00018920).

Synonyms: Glaucium grandiflorum Boiss. \& Huet var. hellisopelma Fedde in Engler, A., Das Pflanzenr., 4, 104: 227 (1909); G. refractum Nab., Publ. Fac. Sci. Univ. Masaryk, Brno, 35: 22 (1923); G. corniculatum (L.) J. H. Rudolph subsp. refractum (Nab.) Cullen, not Roy. Bot. Gard. Edinb., 25: 41 (1963).

Distribution: Turkey, Iran, Caucasus and Iraq.

3. G. calycinum Boiss., Ann. Scienc. Nat. ser. 2, 16: 375 (1841) (Figs. 1B; On-line Suppl. Figs. 1M-Q, 2C-D).

Type: Aucher -Eloy 4042 A, Iran: Esfahan (P00739085).

Description: Biennial herbs, $18-40 \mathrm{~cm}$ high. Stems branched, glabrous or with sparsely hairs at lower part. Stem leaves entire, pinnatifid or sometimes pinnatisect. Buds 1.5-4 $\mathrm{cm}$ long; sepals hairy or sometimes glabrous. Petals $2-4.5 \mathrm{~cm}$ 

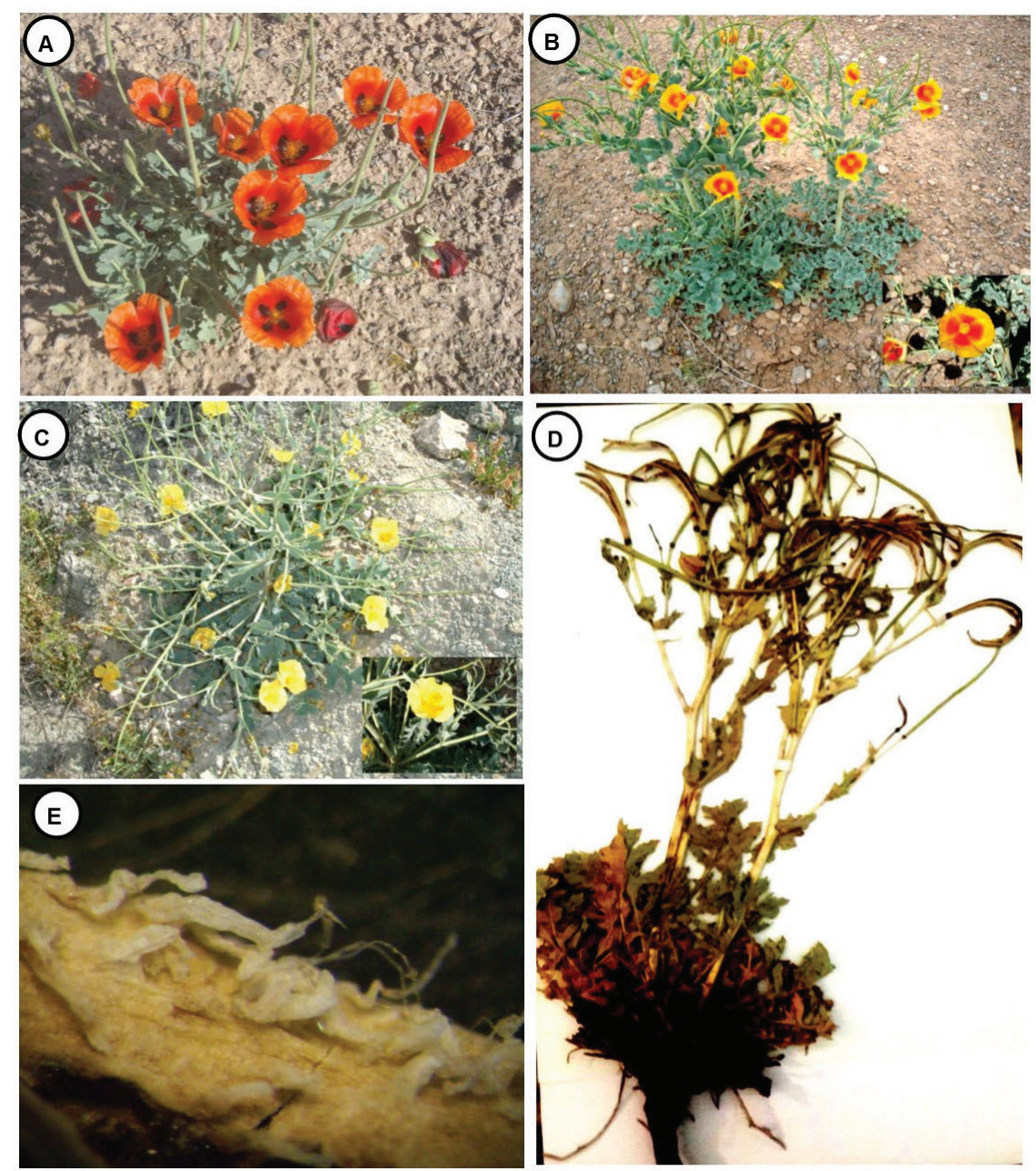

Fig. 1. Photographs of Glaucium species. (A) G. grandiflorum, (B) G. calycinum, (C) G. mathiolifolium, (D) G. yazdianum, (E) G. yazdianum: young siliqua trichomes.

long, yellow and orange at lower part. Stamens numerous; anthers 2-3.5 mm long; filaments broadened at the middle part and narrowed towards the apex and base. Young siliquae with squamiform hairs or sometimes glabrous. Fruiting pedicels up to $10.5 \mathrm{~cm}$ long erect or refracted. Mature siliquae up to 20 $\mathrm{cm}$ long, erect, arcuate or contorted, with remote and nearly spread hairs or glabrescens; stigma 4-9 mm broad.

Phenology: Flowering in mid-May to mid-June and fruiting in early July to late August.

Distribution and habitats: This endemic species is observed from some localities in central, northern and northwestern Iran where it grows on roadsides, hillsides and clayey and bare slopes at 280-2000 $\mathrm{m}$ a. s. 1 .

Mature siliquae erect or arcuate. .. subsp. calycinum

Mature siliquae torulose and contorted. subsp. aserbaidshanicum

G. calycinum subsp. calycinum (On-line Suppl. Tab. 1)

G. calycinum subsp. aserbaidshanicum Mory, Feddes Rep. 9-10: 553 (1979) (On-line Suppl. Tab. 1).
4. G. mathiolifolium Mobayen, Iran. J. Bot. 2: 166 (1984)

(Fig. 1C; On-line Suppl. Tab. 1).

Type: S. Mobayen 9268, 25. 4. 1973, 880 m a. s. 1., Iran (TARI).

Description: Biennial herbs, $25-52 \mathrm{~cm}$ high, dark grey. Stems branched, hairy. Stem leaves entire or lobed, hairy, semi-amplexicaul. Buds 1.5-2 cm long; sepals hairy. Petals up to $2.5 \mathrm{~cm}$ long, yellow and sometimes orange at the base. Stamens numerous; anthers 1.5-3.2 mm long; filaments broadened at the apex, gradually narrowed towards the base. Young siliquae covered with short and long and adpressed hairs. Fruiting pedicels $1.5-2 \mathrm{~cm}$ long. Mature siliquae 6-14 cm long, glabrescens and torulose; stigma 3 $\mathrm{mm}$ broad.

Phenology: Flowering in late March to early April and fruiting in early May.

Distribution and habitats: This endemic species distributed in southwestern Iran on roadsides, dry clayey and calcareous grounds at $500-950 \mathrm{~m}$ a. s. 1 . 
5. G. yazdianum Tavakkoli \& Assadi sp. nov. (Figs. 1D-E; On-line Suppl. Figs. 1A-F, 2A-B; On-line Suppl. Tab. 1).

Type: Iran. Yazd province: Yazd to Taft and Shirkuh, 1200 m a. s. 1., 23 April 1996, Mozaffarian 77379 (holotype TARI!); paratype: Yazd province: Abarkuh, Hossein abad, village, 1400-1600 m a. s. 1., 17 June 2015, Zeraatkar 59935 (FAR); (isotype T!).

Diagnose: Biennial. Stems several. Stem middle leaves broadly oblong, pinnatisect; the segments oblong to lanceolate, lanceolate or triangular, decreasing gradually towards the leaf base. Buds 1.5-2.5 cm long (not up to $4 \mathrm{~cm}$ ); sepals hairy (not with or without hairs). Peduncle $2-6 \mathrm{~cm}$ long, erect (vs $1-10.5 \mathrm{~cm}$, erect or refracted). Filaments monotonic at the upper half and narrowed towards the base (vs broadened at the middle and narrowed towards the apex and base). Young siliquae hairy; hairs multicellular and terminally uniseriate, at lower part oblong and elliptic at the base (vs elliptic or elliptic to oblong at lower part). Mature siliquae 10-12 cm long (not up to $20 \mathrm{~cm}$ ); stigma 6-7 mm broad (not 4-9 $\mathrm{mm}$ ).

Description: Herbs biennial, 30-35 cm high. Stems erect, several, light green to whitish, branching from $10-15 \mathrm{~cm}$ above the base towards the apex, glabrous. Basal leaves $10-18 \times 2-6 \mathrm{~cm}$, with rather moderate and crisp flattened hairs on both surfaces, lyrate-pinnatisect to pinnatipartite; the lower segments triangular, lanceolate, oblong to lanceolate, entire, acute and with apical hairs; the upper segments oblong, oblanceolate, lobed; lobes ovate to triangular, acute, with apical hairs; the terminal segment trilobed; lobes oblong, bi-tridentate at the apex; petioles $2.5-3 \mathrm{~cm}$ long, ribbed, hairy and broadened at the base; stem leaves $1-8 \times 0.5-6 \mathrm{~cm}$, glabrous or with scattered to rather dense hairs, sessile, semi-amplexicaul or with short petiole at lower leaves; upper leaves ovate, ovate-oblong, entire, dentate or pinnatifid; lobes triangular, acute and with apical hairs; middle leaves broadly oblong or obovate, pinnatisect; the segments oblong to lanceolate, lanceolate, triangular, entire or dentate, acute and with apical hairs; the size of segments decreasing gradually towards the leaf base; the terminal segment obovate, trifid, mostly with short lobes at the base; lobes ovate, ovate to lanceolate or triangular, acute and with apical hairs; the lower leaves similar to basal leaves. Buds $1.5-2.5 \times 0.7-1 \mathrm{~cm}$, ovate, attenuate at the apex; sepals with rather dense and crisped hairs. Petals $2-2.5 \times 2-4 \mathrm{~cm}$, yellow and with basal orange spot. Stamens numerous, shorter or longer than ovary; anthers 3-5.2 mm long, cylindrical to oblong; filaments monotonic at the upper half, broadened at the middle part and gradually narrowed towards the base. Young siliquae covered with hair and glabrous at the base; hairs multicellular, multiseriate and terminally uniseriate, flattened and somewhat crisped, $0.48-2.58 \mathrm{~mm}$ long. Fruiting pedicels $2-6 \mathrm{~cm}$ long, erect. Mature siliquae $10-12 \mathrm{~cm}$ long and $2-3 \mathrm{~mm}$ in diameter, gradually narrowed towards the apex, hairy; stigma 6-7 $\mathrm{mm}$ broad.

Phenology: Flowering occurs in late April to June with fruiting during June-July.

Etymology: The specific epithet refers to the type locality in Yazd province.
Distribution and habitats: Glaucium yazdianum is known from central Iran in Yazd province in two populations sites. The locality is considered an element of the Irano-Turanian floristic region. The species grows on hills and flat areas of clay and stone and roadsides at altitudes of 14001600 m a.s. 1.

Conservation status: G. yazdianum has been collected from two localities in Yazd province, Iran. The known area of occupancy is less than $500 \mathrm{~km}^{2}$ (criterion $\mathrm{B}_{2}$ ) and estimated number of mature individuals is fewer than 2500 (criterion C). Therefore, according to IUCN categories (IUCN 2017) we propose the conservation status of the species as endangered.

Similar species: G. yazdianum is similar to G. calycinum in habit, petal color and shape of basal leaves, but differs from it by cellular structure, length and shape of trichomes on Young siliquae (Fig. 1E, Online Suppl. Fig. 2A) and sepals (On-line Suppl. Fig. 2B), siliqua and bud length, the shape of stem leaves and filaments (On-line Suppl. Tab. 2, On-line Suppl. Fig. 1B-F). The two species are compared in On-line Suppl. Tab. 2.

Leaf anatomy: The main features of leaf epidermis of the examined species are studied. The shape of epidermal cells on the adaxial and abaxial surfaces is polygonal and nearly irregular with anticlinal walls of straight to curved or nearly undulate in G. yazdianum and G. calycinum. These two taxa show differences in the length and width of stomata on both surfaces: the average of the stomata size of adaxial surface is $45.84 \times 37.2 \mu \mathrm{m}$ in G. yazdianum and $39.4 \times 32.48 \mu \mathrm{m}$ in $G$. calycinum, while on the abaxial surface it is $47.18 \times 38.9 \mu \mathrm{m}$ and $38.2 \times 25.27 \mu \mathrm{m}$ in G. yazdianum and G. calycinum, respectively. Anomocytic stomatal and anisocytic types occur on the both sides of leaves, which are more numerous on the abaxial side (On-line Suppl. Figs. 4A-D).

Palynology: Pollen grains of G. yazdianum and allied species are single, radially symmetrical, isopolar and tricolpate. The shape of pollen grains ranges from sub-prolate in G. yazdianum to prolate-spheroidal in G. calycinum. The size of pollen grains (polar axis $\times$ equatorial axis) is 34.81 $(31.4-38.53) \times 29.99(20.08-31.75) \mu \mathrm{m}$ in G. yazdianum and $32.79(28.82-44.43) \times 31.26(21.82-41.64) \mu \mathrm{m}$ in $G$. calycinum (On-line Suppl Figs. 4E-H).

6. G. contortuplicatum Boiss., Ann. Scienc. Nat. ser. 2, 16: 376 (1841) (Fig. 2A).

Type: Aucher-Eloy 4042, 1889, Iran: Gilan (type: W0077474).

Description: Herbaceous biennial, $12-50 \mathrm{~cm}$ high. Stems pale green to purplish, with dense and corymbose branches. Stem leaves entire, dentate to pinnatifid or sometimes pinnatisect. Buds $0.8-1.7 \mathrm{~cm}$ long; sepals glabrous or hairy. Petals $0.8-1.8 \mathrm{~cm}$ long, yellow and orange at the base. Stamens numerous; anthers 1-2 mm long; filaments slender and attenuate towards the base. Young siliquae covered with hairs 0.13-0.82 mm long. Fruiting pedicels $1-6 \mathrm{~cm}$ long, contorted. Mature siliquae $4.5-18 \mathrm{~cm}$ long, with remote hairs or gla- 

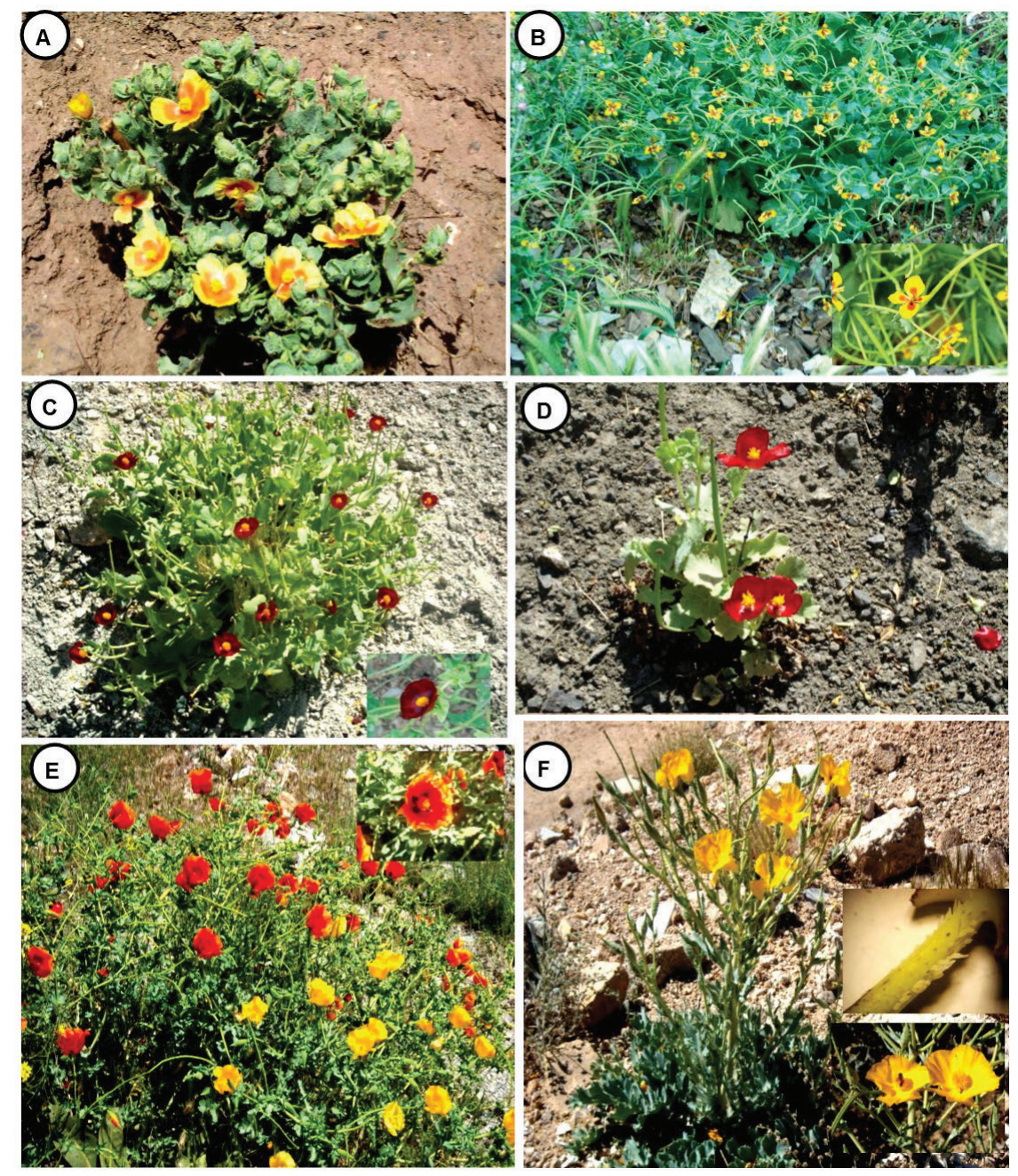

Fig. 2. Photographs of Glaucium species. (A) G. contortuplicatum, (B) G. elegans var. elegans, (C), (D) G. oxylobum, (E) G. flavum, (F): G. vitellinum var. pilosum.

brescens, torulose, contorted or strongly contorted; stigma 4-7 mm broad. July.

Phenology: Flowering and fruiting in late May to early

Distribution and habitats: Endemic to Iran, distributed in northern, northwestern, central Iran where it grows in fields, on roadside slopes and wet or salty soils at 220-2630 ma.s. 1 .

Young siliquae hairy at the apex ..........var. contortuplicatum Young siliquae totally hairy. var. hirsutum

Glaucium contortuplicatum var. contortuplicatum (On-line Suppl. Tab. 1).

Glaucium contortuplicatum var. hirsutum Tavakkoli \& Assadi, Nova Biol. Reperta 3: 169

(2016) (On-line Suppl. Tab. 1).

Type: Z. Tavakkoli 54331, 27. 6. 2013, 520 m a. s. 1., Iran: Gilan, 95 km Rasht (FAR).
7. G. elegans Fisch. \& C. A. Mey., Ind. Sem. Hort. Petrop. 1: 29 (1835) (Fig. 2B; On-line Suppl. Tab. 1).

Type: Fischer and Meyer s. n., northern Iran (LE).

Description: Annual herbs, 5-38 cm high, green or glaucous. Stems branched. Stem leaves entire, dentate to lobed or pinnatisect. Buds 6-26 mm long; sepals glabrous or hairy. Petals 11-22 mm long, yellow to orange and with black basal spot. Anthers 1-1.5 mm long; filaments monotonic in upper half and broadened in lower part. Young siliquae hairy. Fruiting pedicels $0.5-4 \mathrm{~cm}$ long. Mature siliquae $7-16 \mathrm{~cm}$ long, torulose, arcuate or slightly contorted at the apex, with nearly patent hairs; stigma $2 \mathrm{~mm}$ broad.

Phenology: Flowering in late April with mature fruits in mid-June to mid-July.

Distribution and habitats: Iran, central Asia, Afghanistan and Pakistan. G. elegans is the most widespread species in Iran with a distribution on dry slopes, wet or gypsiferous soils and weedy stony localities at $180-3000 \mathrm{~m}$ a. s. 1 . 
Plants covered with hairs; young and mature siliquae hairy var. elegans

Plants glabrous; young and mature siliquae glabrous. var. bornmulleri

\section{Glaucium elegans var. elegans}

Synonyms: G. pumilum Boiss., Ann., Sc. Nat., 2. Ser., 16: 374 (1841); G. elegans var. integerrima Mobayen, Fl. Iran, Vas. Pl. 155 (1985).

Glaucium elegans var. bornmulleri Fedde, Feddes Rep. 3, 215: (1909).

Type: Bornmuller 6087 b, 13. 6. 1900, 2200 m, northern Iran: Elburz mountain, Shahrestanak valley (type: JE 00018896).

8. G. oxylobum Boiss. \& Buhse, Nouv. Mem. Soc. Nat. Mosc. 12: 12 (1860) (Figs. 2C, D, On-line Suppl. Fig. 3A; On-line Suppl. Tab. 1).

Type: Buhse 1140, 8. 1848, Iran: Radkan (LE 00012800).

Description: Biennial herbs, 5-35 cm high. Stems glaucous, glabrous or hairy at lower part. Stem leaves glabrous or with scattered to moderate hairs, dentate, pinnatifid or sometimes pinnatisect. Buds 1-3.5 cm long; sepals glabrous or sometimes with scattered hairs. Petals $1-4.5 \mathrm{~cm}$ long, dark red to violet, reddish orange or sometimes yellow, with or without black middle spot. Stamens numerous; anthers 1-4 $\mathrm{mm}$ long; filaments broadened at the apex, gradually attenuate towards the middle and base. Young siliquae with tubercles, papillose, tubercles narrowed at the apex, conical hairs or glabrous; trichomes at the apex or all along young siliqua. Fruiting pedicels 1-6 cm long, erect or contorted. Mature siliquae $8-28 \mathrm{~cm}$ long, strongly thickened at the base, erect, arcuate or contorted, with remote and nearly patent hairs or glabrous; stigma 3-10 mm broad.

Phenology: Flowering in late April to early June and fruiting in mid-June to late July.

Young siliquae glabrous; mature siliquae up to $15 \mathrm{~cm}$ long.. .. var. paucilobum

Young siliquae covered with tubercle or hair; mature siliquae up to $28 \mathrm{~cm}$ long ..var. oxylobum

\section{Glaucium oxylobum var. oxylobum}

Synonyms: G. pulchrum Stapf, Donkschr. Akad. Wiss. Wien Math. -Nat. Kl, 51: 295 (1886)

\section{syn. nov.}

Type: T. Pichler, 23. 4. 1882, northern Iran: Rostamabad (syntype: WU0067323); T. Pichler s.n. 1882, northern Iran: Pachenar (syntype: WU0067324). G. elegantissimum Mobayen, Iran J. Bot. 2: 163 (1984) syn. nov. Type: T. Hewer, 3834, 22. 5. 1976, 650 m a. s. 1., Iran: Golestan: 22 km Marave Tappeh on road to Gonabad (TARI). G. golestanicum Gran \& Sharifnia, Iran, J. Bot. 14: 26 (2008) syn. nov. Type: A.
Gran 44265, 15. 4. 2006, 153 m a. s. 1., Iran: Golestan, Marave Tappeh to Gonabad, Chad zone (TARI).

Distribution and habitats: Distributed in Europe, Iran and Central Asia. This taxon is found in north, northeastern and central Iran in the semi-desert zone, on clayey slopes, stony mountains, hillsides and on the wet or gypsiferous soils at $180-2740 \mathrm{~m}$ a. s. 1 .

Glaucium oxylobum var. paucilobum (Freyn) Parsa, Fl. Iran, 2: 444 (1986).

Type: -Sintenis, P. E. E., Turkmenistan: Kisil Arwat, Karakaia, Joldere valley (LE 00018946).

Synonym: G. paucilobum Freyn, Bull. Herb. Boiss. ser. 2, 3: 366 (1903).

9. G. flavum Crantz, Stirp. Austr., ed. 1, 2: 133 (1763) (Fig. 2E, On-line Suppl. 3B-D).

Type: Anon. s. n. (Lectotype LINN-668-3).

Synonyms: Chelidonium glaucium L., Sp. Pl., ed. 1: 506 (1753); G. luteum Scop., Fl. Carn., ed. 2, vol. 1: 369 (1772); G. leiocarpum Boiss., Fl. Or. 1: 122 (1867).

Description: Biennial herbs, $28-65 \mathrm{~cm}$ high. Stems whitish, glabrous and branched. Stem leaves pinnatifid to pinnatisect. Buds 0.8-3 cm long; sepals covered with crisped hairs or sometimes glabrous. Petals $1.5-4.5 \mathrm{~cm}$ long, yellow, yellow to orange, orange red, with or without spot. Stamens numerous; anthers 1-3 mm long; filaments broadened at the apex and gradually narrowed towards the base. Young siliquae covered with white tubercles at over most of length or upper part. Fruiting pedicels $1-5 \mathrm{~cm}$ long, erect. Mature siliquae 8-19 cm long, glabrescent or sometimes with remote and white tubercles, torulose or not, erect or arcuate; stigma 2.5-5.5 mm broad.

Phenology: Flowering in late May with mature fruiting in mid-June to mid-August.

Distribution and habitats: Europe, Turkey, Iran, Caucasus, Syria and northwestern Africa in roadsides, clayey and rocky slopes and hillsides at 1350-3100 m a. s. 1 .

The varieties of this species have been described on the base of flower color:

Petals yellow and without spot var. flavum Petals yellow and orange at lower part or reddish orange, with violet basal spot and spot, with or without yellow margin. .var. serpieri

Glaucium flavum var. flavum (On-line Suppl. Tab. 1).

Glaucium flavum var. serpieri (Heldreich) Halacsy, Consp. Fl. Graec., 1: 41 (1901) (On-line Suppl. Tab. 1).

Type: Heldreich s. n., Greece, Attica in Surrotimis Lanruz (Laurium) (K 000653298).

Synonym: G. serpieri Heldreich, In: Regel, Gartenfl., 22: $323\left(1873^{\prime}\right)$. 


\section{G. vitellinum Boiss. et Buhse, Fl. Or. 1:122 (1867) (Fig. 2F)}

Type: Buhse s. n., Iran: Yazd (type: P00739088).

Synonyms: G. flavum var. vitellinum (Boiss. \& Buhse) Mobayen, Fl. Iran, Vac. Pl. 158 (1985) nom. inval.; G. flavum subsp. vitellinum (Boiss. \& Buhse) Mobayen, Fl. Iran, Vasc. Pl. 168 (1985,) nom. inval.

Description: Herbaceous biennial, $27-75 \mathrm{~cm}$ high, stems glaucous or whitish, glabrous or with scanty hairs on lower part, branched. Stem leaves dentate, pinnatifid to pinnatisect. Buds 1.5-5 cm long; sepals with or without hair. Petals 2-3.5 $\mathrm{cm}$ long, yellow, luteous, with or without orange basal spot. Stamens numerous; anthers 2-4 mm long; filaments broadened at the apex and gradually narrowed towards the base, sometimes broadened at the lower part. Young siliquae glabrous or sometimes hairy. Fruiting pedicels $1-10 \mathrm{~cm}$ long, erect. Mature siliquae 8-24 cm long, glabrous or sometimes with scattered and short hairs; stigma 5-9 mm broad.

Phenology: Flowering and fruiting occurs in May-July.

Distribution and habitats: G. vitellinum is distributed in Fars, Yazd, Kerman and Hormozgan provinces, Iran. It is an Irano-Turanian and Sahara-Sindian geoelement and grows in clayey and stony flat areas, on roadsides and on dry hills at altitudes of 500-2200 $\mathrm{m}$ a. s. 1 .

Young and mature siliquae glabrous ................var. vitellinum Young and mature siliquae hairy at the apex .....var. pilosum

Glaucium vitellinum var. vitellinum (On-line Suppl. Tab. 1).

Glaucium vitellinum var. pilosum Tavakkoli \& Assadi var. nov. (On-line Suppl. Figs. 1G-L, 3E-F).

Holotype: Iran. Fars province. $30 \mathrm{~km}$ on the road from Firoozabad to Gheer, 1260 m a. s. 1., 23 April 2005, Safavi 87623 (TARI!).

The distinctive feature of the variety is the occurrence of hairs on the young siliquae near the apex. We observed the specimens of var. pilosum along with type variety in a population.

\section{Discussion}

This study documents the occurrence of 10 species, 4 subspecies and 14 varieties belonging to the genus Glaucium that have been found in Iran. Some of the species are synonymous (G. pulchrum, G. golestanicum and G. elegantissimum). Two new taxa are recognized, including one new species ( $G$. yazdianum) and on new variety (G. vitellinum var. pilosum). G. fimbrilligerum is not found in Iran. The taxonomically most valuable characters in the genus are: the shape and cellular structure of trichomes on young fruits and sepals, the shape of stem leaves and filaments, the length of siliquae, anther and buds (On-line Suppl. Tab. 2).

G. corniculatum subsp. refractum (Nab.) Cullen with refracted fruiting pedicels and contorted siliquae was reported from western Iran (Cullen 1966). One of the diagnostic characteristics of G. corniculatum is fruiting pedicels that are shorter than their subtended leaves while a reported speci- men in Flora Iranica (Farahbakhsh 5956; deposited in IRAN herbarium) has fruiting pedicels longer than their subtended leaves as G. grandiflorum. Hence, similar to Mory's view, $G$. grandiflorum subsp. refractum (Nab.) Mory is used.

G. haussknechtii was described as a distinct species possessing numerous short stems (up to $15 \mathrm{~cm}$ long). Based on a study of herbarium and collected materials (deposited in TARI, FAR and IRAN) (Cullen 1966) we observed some specimens with a main stem and a height up to $15 \mathrm{~cm}$ long and plants with numerous stems with a height of $22-28 \mathrm{~cm}$. Therefore, our studies support Mory's hypothesis that $G$. haussknechtii is a synonym of G. grandiflorum.

Regarding G. yazdianum, micromorphological characters including stomata size and the shape and size of pollen grains inform the separation of this species from $\mathrm{G}$. $c a$ lycinum.

The main characteristics of G. oxylobum have been reported to be: ovaries tuberculate-papilate and petals yellow (Cullen 1966); ovaries (young siliquae) with tubercles narrowed at the apex and petals dark red to violet (Boissier 1867); ovaries with conical hairs and petals pale red with black basal spot (Mory 1979).

G. pulchrum Stapf was separated from G. oxylobum by its height up to $20 \mathrm{~cm}$ long (vs up to $50 \mathrm{~cm}$ ) and glabrous sepals (vs hairy sepals) and dark red-violet petals (vs yellow) as well as by siliquae covered with patent and short hairs (vs tuberculate-papilate or glabrescens) by Cullen (1966). Mory (1979) described this species with a height up to $20 \mathrm{~cm}$ long and pale red petals with a black basal spot and ovaries covered with bristles $0.5-1 \mathrm{~mm}$ long and siliquae with a length of up to $15 \mathrm{~cm}$ long.

G. paucilobum Freyn was reported as a distinct species that is glabrous in all parts and has petals that are yellow in dry stage (Cullen 1966).

G. elegantissimum with glabrous siliquae and dilute red petals and G. golestanicum possessing hairy siliquae and red petals with a black basal spot and maculate leaves were accepted as new species by Mobayen (1985) and Gran and Sharifnia (2008), respectively. Our observations on the type materials showed that both species have tuberculate young siliquae and orange red petals with a black middle spot.

Based on field observations and studies of many herbarium specimens, we found many intermediate forms that had a height up to $20 \mathrm{~cm}$ long or more. In all of these specimens, young siliqua trichomes were tubercular or tubercles narrowed at the apex or a triple indumentums consisting of conical hairs mixed with tubercles and tubercles narrowed at the apex. They had dark red or reddish orange petals (with or without spot) or yellow and glabrous sepals (rarely hairy). Mature siliquae were glabrescens or with nearly spreading hairs with the length of 8-28 cm, strongly thickened at the base and erect, arcuate or contorted. On the other hand, plants with glabrous ovary and siliqua were found in the populations of G. oxylobum.

Based on the mentioned variations, the specimens of $G$. oxylobum fall into two groups with respect to young siliqua 
indumentum, which is either glabrous or hairy with petal color variations in each group. Hence, the separation of the species G. pulchrum, G. elegantissimum and G. golestanicum from G. oxylobum is not possible and we suggest their synonymy with G. oxylobum here. We agree with Parsa's suggestion (1986) to regard G. paucilobum as a variety of $G$. oxylobum.

Diagnostic characteristics of G. fimbrilligerum Traut \& Buhse are maculate orange petals and sepals with the length of $20 \mathrm{~mm}$ long and they possess long and adpressed hairs on the siliquae (Cullen 1966). A detailed examination of the species G. fimbrilligerum (deposited in W herbarium-No. ooo4645-Afghanistan: Chord Kabol, 2070 m, 6. 8. 1951, Gilli 866) with a particular focus on the trichome cellular structure of young siliquae, provides strong support for the proposal that this species has not been found in Iran so far.

Glaucium vitellinum was mainly characterized by glabrous siliquae (young siliquae) and yellow petals from Yazd (Boissiera 1867). Among investigated herbarium specimens, we recognized the specimens of the genus Glaucium with glabrous or sometimes hairy siliquae and buds. They had yellow petals and with or without orange basal spot. Filaments were broad at the apex (sometimes at lower part) and gradu-

\section{References}

Boissiera, E., 1867: Glaucium. In: Geor, H. (ed.), Flora Orientalis 1, 119-123. Genevae et Basileae.

Cullen, J., 1966: Glaucium. In: Rechinger, K. H. (ed.), Flora Iranica 34, 2 -7. Akad. Druck- und Verlagsanstalt.

Erdtman, G., 1986: Pollen morphology and plant taxonomy, Angiosperms. In: Brill, E. J. (ed.), 1-553. Leiden, The Netherlands.

Ernest, W. R., 1962: A comparative morphology of Papaveraceae, PhD Dissertation. Standford University, Standford, California.

IUCN, 2017, Guidelines for using the IUCN Red List Categories and Criteria, version 13. Gland \& Cambridge. Retrieved from httpp://www.iucnredlist.org/documents/redlist Guidelines.pdf.

Gran, A., Sharifnia, F., 2008: Micro-macrophological studies of the genus Glaucium (Papaveraceae) in Iran. The Iranian Journal of Botany 14, 22-38.

Hesse, A., Halbrilter, H., Zelter, R., Weber, M., Buchner, R., Frosch-Radivo, A., Ulrich, S., 2009: Pollen Terminology, an illustrated handbook, 1-266. Springer, NewYork.

Hoot, S. B., Kadereit, J. W., Blattner, F. R., Jork, K. B., Schwarzbach, A. E., Crane, P. R. 1997: Data congruence of the Papaveraceae s. 1. based on four data sets: atpB and $r b c L$ sequences, $\operatorname{trnK}$ restriction sites, and morphological characters. Systematic Botany 22, 575-590. ally attenuate towards the base but abruptly narrowed below the anthers. Sometimes these specimens were observed on a single sheet together. On the other hand, we encountered individuals that had either glabrous or hairy siliquae in a single population in the fieldwork in Fars and Yazd provinces. Buds of these specimens were glabrous or hairy and they possessed yellow petals, with or without orange basal spot. Thus we regard the specimens with hairy siliquae as a new variety as G. vitellinum var. pilosum. Mory (1979), Cullen (1966) and Mobayen (1985) respectively reduced G. vitellinum as a synonymy of G. calycinum, G. oxylobum and the variety of $G$. flavum. Although hairy or glabrous siliquae were observed among the members of the species G. calycinum, G. oxylobum and sometimes G. flavum, the morphological and micro-morphological investigations of trichomes reveal clear differences among the mentioned species and G. vitellinum. Although G. flavum and some of the specimens of $G$. oxylobum have tubercular trichomes on their young siliquae, the trichome micro-morphological characteristics of G. vitellinum var. pilosum (on young siliquae and sepals) show considerable differences from the other species of Glaucium here (On-line Suppl. Tab. 2, On-line Suppl. Figs. 2A-D, 3A-F). G. vitellinum is also characterized by the shape of its leaves and filaments (On-line Suppl. Tab. 2, On-line Suppl. Figs. 1G-L).

Kadereit, J. W., 1993: Glaucium. In: Kubitzki, K. Rohwer, J. C., Bittrichotteidedelberg (eds.), The families and Genera of Vascular Plants, 1-663. Springer Verlag, Berlin.

Kadereit, J. W., Blattner, F. R., Jork, K. B., Schwarzbach, A. E., 1994: Phylogenetic analysis of the Papaverceae s. 1. (including Fumariaceae, Hypecoaceae and Pteridophyllum) based on morphological characters. Botanische Jahrbücher für Systematik und Pflanzengeographie 116, 361-390.

Mobayen, S., 1985: Glaucium. In: Flora of Iran, vascular plants 3, 154 -170. Tehran University, Iran.

Mory, B., 1979: Beitragezur Kenntnis der Sippenstruktur der Gattung Glaucium Miller (Papaveraceae). Feddes Repertorium 39, 499-595.

Parsa, A., 1986: Glaucium. In: Flora of Iran 2, 428-446. National Scientific Research Council Tehran, Iran.

Payne, W. W., 1978. A Glossary of Plant hair terminology. Brittonia $30,239-255$

Tavakkoli, Z., 2016: Notes on some species of the genus Glaucium (Papaveraceae) in Iran. Nova Biologica Reperta 3, 167-176.

Vafadar, M., Attar, F., Maroofi, H., 2010: Trichome micromorphology in drupe of Amygdalus L. (Rosaceae) from Iran. Acta Botanica Croatica 69, 93-105.

Van Cotthem, R. J., 1970: Classification of stomatal types. Botanical Journal of the Linnean Society 63, 235-246. 